DOI https://doi.org/10.30525/978-9934-26-109-1-32

\title{
ІНТЕГРОВАНИЙ МЕТОД ВИВЧЕННЯ КОНСТРУКЦІЇ АВТОМОБІЛЯ ДЛЯ ПІДГОТОВКИ ЙОГО ДО ЕКСПЛУАТАЦІї
}

\author{
Петров Л. М. \\ кандидат технічних наук, доцент, \\ викладач кафедри автомобільної техніки \\ Військова академія (м. Одеса)
}

Kiшянус I. B.

старший викладач кафедри автомобільної техніки

Військова академія (м. Одеса)

Нікішин В. А.

викладач кафедри автомобільної техніки

Військова академія (м. Одеса)

м. Одеса, Украӥна

Розвинена національна інноваційна структура являється умовою забезпечення вступу держави в число з відповідним технологічним укладом, а оволодіння інноваційною діяльністю інженерних кадрів залогом технічного прогресу суспільства. У зв'язку з цим інноваційна підготовка являється важливим і необхідним компонентом навчання у військовій академії, що підтверджується утриманням навчальних стандартів. Така підготовка формує у тих, хто навчається компетентності в інженерній праці.

Назва «групове заняття» являється однією 3 форм практичного навчання курсантів в академії і пов'язане з використанням розумових та фізичних зусиль по відшуканню раніше невідомих шляхів та засобів вирішення виникаючих проблем, вплив зв'язків теорії з практикою. Головною задачею групового заняття $\epsilon$ встановлення зв'язків теорії 3 практичними розрахунками та перевірка на спеціально обладнаних приладах. При цьому, у курсантів розширюється кругозір, формується мотивація до вивчення дисципліни, а також активацію творчого потенціалу [1, с. 37-42].

При підготовці до групового заняття курсант вивчає питання теорії, яка була перевірена, примушує курсанта під час семестру систематично 134 
вивчати теоретичні курси, що дозволяє підняти рівень його знань. Усе це систематизує процес навчання, забезпечує засвоєння матеріалу, а це підвищує ступень професійної підготовки курсанта.

Групові заняття інтегрують теоретико-методологічні знання, практичні вміння та навички курсантів у процесі діяльності учбоводослідницького характеру. Це активізує пізнавальну діяльність курсантів, придає конкретний характер того, що вивчається на лекціях i в процесі самостійної роботи 3 теоретичним матеріалом, сприяє детальному i міцному засвоєнню навчальної інформації. При виконанні більшості групових робіт курсанту дається можливість стати «відкривачем», що сприяє розвитку пізнавального інтересу чи отримати учбовий інноваційний продукт [2, с. 11-15].

При вивченні дисципліни «Автомобілі» майбутньому спеціалісту необхідно знати, сукупність яких властивостей вони повинні мати, щоб виконати відповідні робочі функції.

Метою створення авторської методики для підготовки майбутнього військового спеціаліста являється закріплення отриманих курсантом знань при вивченні дисципліни «Автомобілі», формування навичок використання теоретичних розрахунків для підвищення показників ефективності експлуатації автомобілів.

Основною задачею проведення групового заняття являється розрахунок та вибір параметрів (ваги, потужності двигуна, передаточних чисел трансмісіі, міцнісних розрахунків деталей) які забезпечують до основних досягнень оптимальних тягово-швидкісних, паливо-економічних показників та других, які відображають основні показники експлуатаційних властивостей автомобілів. В задачу вивчення дисципліни також входять технологічні розрахунки елементів шасі, трансмісії і ходової частини автомобіля.

Розрахунки деталей та вузлів машин розглядаються у загально технічній дисципліні «Деталі машин та основи конструювання». Але, принципи та методики розрахунку відрізняються від тих, що вивчаються в дисципліні «Автомобілі». Розрахунки ведуться 3 використанням навчально - методичної та довідкової літератури.

Запропонована методика викладання групового заняття 3 дисципліни «Автомобілі» за методом інтерактивного навчання.

При організації інтерактивної навчально-пізнавальної діяльності курсантів з урахуванням інтересів і запитів життєвого і професійного досвіду у формах партнерської взаємодії всіх курсантів взводу, які $є$ учасниками навчального процесу. В запропонованій методиці застосовані принципи інтерактивного навчання; діалогова взаємодія, 
кооперація та співробітництво, активно-рульова i тренінгова організація навчання (рис. 2).

Виконання інтерактивної технології кооперативно-групового навчання було застосовано елементи; позитивна взаємозалежність (успіх кожного курсанта групи залежить від іншого курсанта цієї групи, кожен курсант має свої обов'язки (знати сам і забезпечити вивчення матеріалу іншим членом (курсантом) групи, кожен має усвідомлювати значення цієї взаємозалежності та координувати свої зусилля з товаришами по групі);

Особиста відповідальність - у групі не можна «сховатись»; оцінювання кожного іншими членами групи;

Особистісна взаємодія (обличчям до обличчя): члени групи пояснюють, сперечаються, співпрацюють і пов'язують матеріал, вивчений сьогодні, з тим, який вони засвоїли раніше;

Групова обробка результатів: обговорення членами кооперативних груп питання функціонування групи - наскільки ефективно вона працювала для розв'язання навчальних завдань.

Діяльність створених груп по рішенню проблемного питання охоплює наступні етапи: 3'ясування змісту, значення понять та термінів; визначення та аналіз проблеми та іiі наслідків, тобто розбиття іiі на складові елементи чи задачі; розподілення за важливістю виділених елементів ( задач та встановлення зв'язку між ними; пошук додаткової інформації; оформлення звіту щодо відпрацьованої роботі, іiі рецензування та самооцінка; демонстрування звіту перед взводом з описом вибраного метода рішення та його обгрунтування. Рівень засвоєння матеріалу групового заняття оцінюється у процесі захисту звітів по виконаним роботам по розділу 3 урахуванням виконання курсантами строків та вимог до змісту зі шкалою балів.

Самостійна робота курсантів по дисципліні «Автомобілі» включає:

- підготовку до лекційних занять (вивчення окремих питань по рекомендованої літературі, конспектування літературних джерел, опрацювання матеріалів лекцій);

- підготовку до практичних занять (оформлення звітів по практичним роботам); Рівень компетенції, сформованих в результаті виконання робіт, які засвоюються самостійно, оцінюється в процесі їх захисту у відповідності з бально- рейтинговою системою [3,61-67].

\section{Висновки.}

Приведено раціоналізаторський вид педагогічного досвіду, використання якого дозволяє розкрити: 

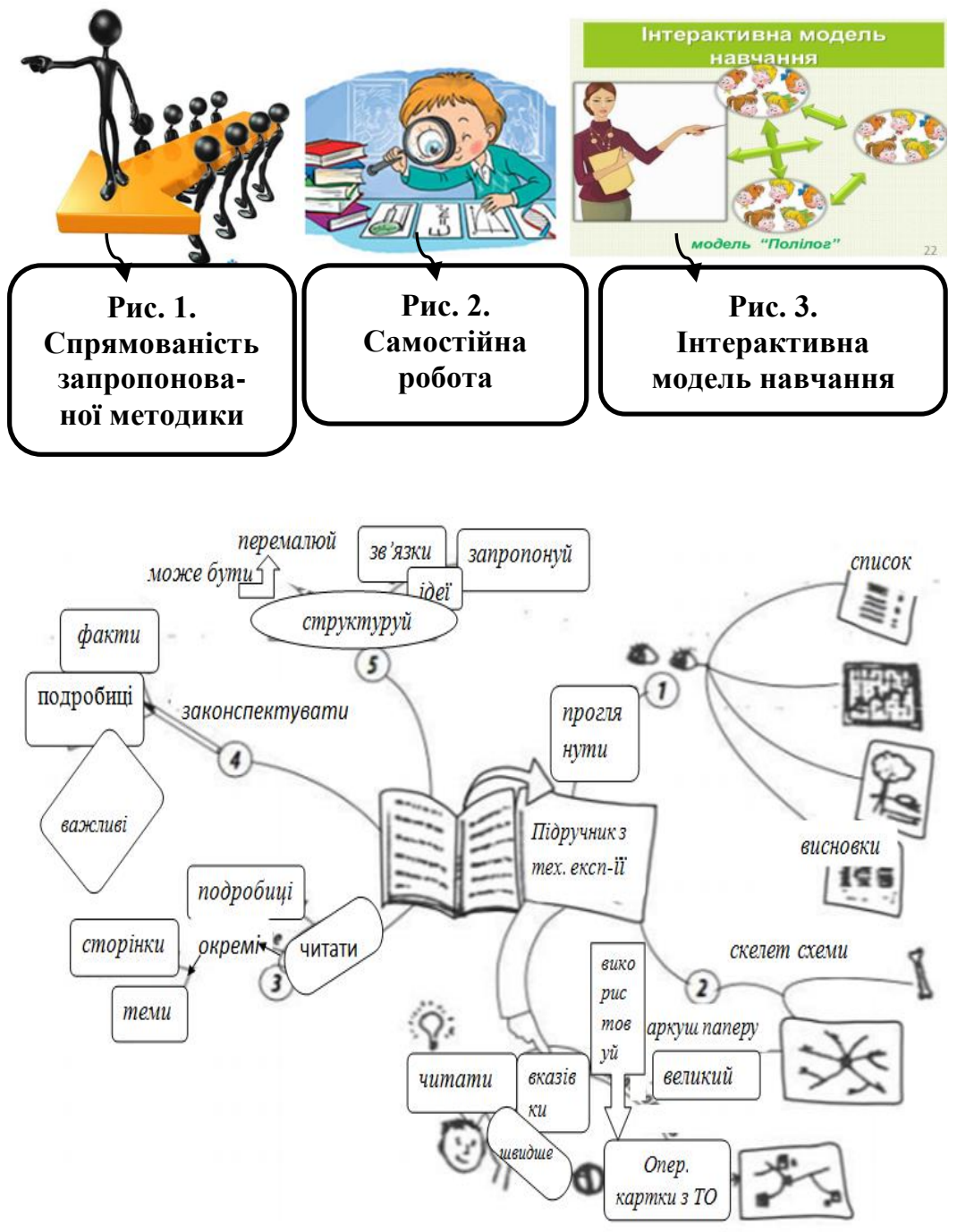

Рис. 4. Асоціативна операційна карта для проведення групового заняття 


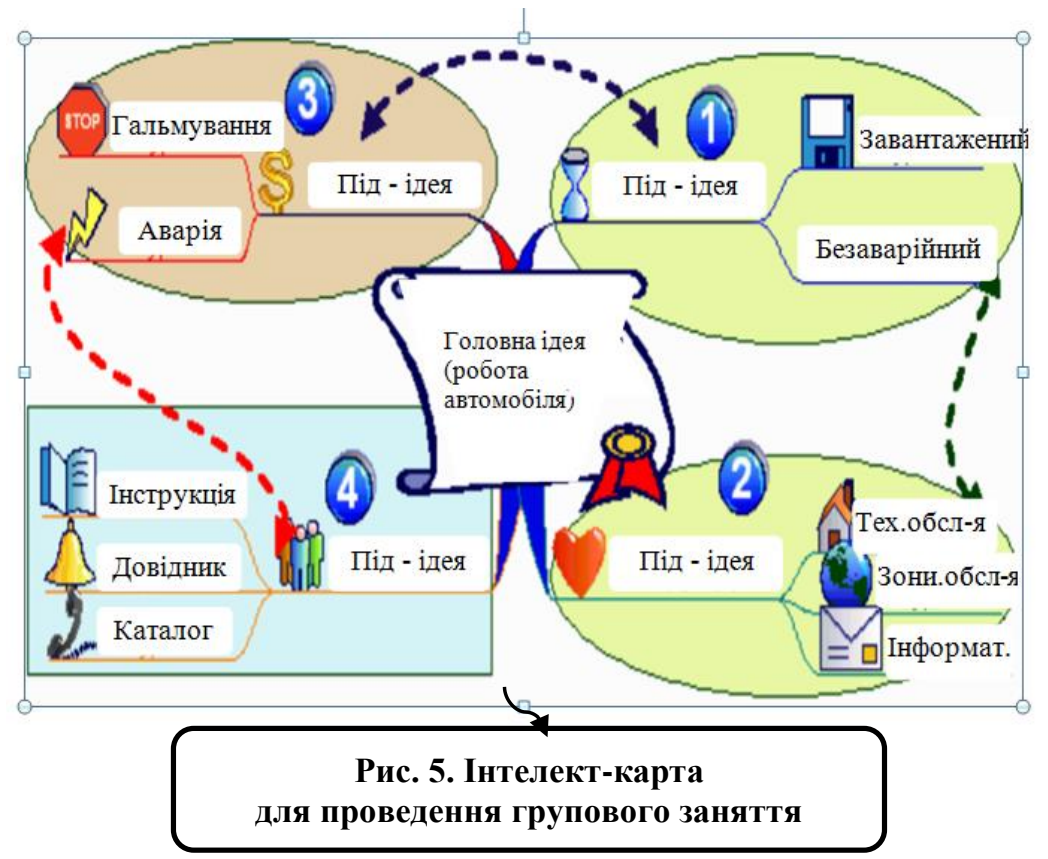

- глибину, проблемність та критичність мислення;

- відкритість, готовність до діалогу, толерантність до чужої точки зору, чуйність до курсанта;

- гнучкість у пошуках альтернативних підходів до вирішення проблеми;

- варіантність та пластичність в комунікативних стратегіях;

- особиста участь у процесі інтерактивного навчання, у сполученні з відповідальністю за вибір рішення.

\section{Література:}

1. Сисоєва С.О. Інтерактивні технології навчання дорослих: навчально-методичний посібник / упоряд. С.О. Сисоєва; НАПН України. Ін-т педагогічної освіти і освіти дорослих.К.: ВД «ЕКМО», $2011.324 \mathrm{c}$.

2. Томс Урдзе. Посібник для фахівців 3 навчання дорослих. Київ, $2016.84 \mathrm{c}$.

3. Інтерактивні методи навчання: навч. посібник / за заг. ред. П. Шевчука і П. Фенриха. Щецін:WSAP, 2005.170 с. 